treat a tuberculous patient with greatest advantage, and that evén he can do little without the hearty co-operation of his patient.

Many interesting questions are raised by Dr. Hinsdale; he gives numerous excellent and interesting illustrations of shelters, of institutions, of methods of treatment, of the results of heliotherapy and immobilisation in plaster; he delineates patients before treatment, patients during treatment, in plaster jackets and in sun baths, and patients after treatment, and altogether makes us feel that the publication is what it pretends to be, a collection of data that will interest those engaged in the treatment of tubercular patients. With all this it is a constant matter for regret that the author has not put a little more of himself into his work. For what it is, however, we are grateful, and it may be anticipated that it will be very widely consulted.

\section{THE BRITISH ASSOCIATION IN}

\section{TASMANIA.}

THE Tasmanian contingent of the British Assuciation left Melbourne by the s.s. Loongana on Saturday, September 5, at 10.30 p.m., and arrived at Launceston about 5 p.m. on the following day. The party numbered twenty-one. Owing to an unfortunate dislocation in the boat service it was impossible to carry out the Launceston portion of the original programme, although time was found to visit the Launceston Museum on Sunday evening, under the guidance of the curator, Mr. H. H. Scott, to whose zeal and energy this excellent little museum owes so much. On the following day there was just time for a brief visit to the beautiful Cataract Gorge before leaving by rail for Hobart. Tuesday, September 8, was occupied by receptions at the Hobart Town Hall, the museum, and the university, and a luncheon at Government House, and in the evening Dr. G. T. Mcody gave a lecture on some commercial aspects of education. Wednesday, September 9, was devoted to a motor excursion to Mount Wellington, the party being entertained at lunch at the Springs Hotel by the Hon. Henry Dobson, who has done so much to open up Mount Wellington as a tourist resort. Some of the party proceeded on foot from the Springs to the summit, while others devoted themselves to the collection of natural history specimens, including the remarkable "mountain shrimp," Anaspides tasmaniae, so characteristic of the mountain streams of the island.

On Thursday, September ro, the party divided for several excursions in the neighbourhood of Hobart, including a dredging trip to the D'Entrecasteaux Channel, which resulted in the collection of much interesting material. On the following day they left for Maria Island. on the east coast, proceeding by motor as far as Spring Bay, whence the crossing to the island was made by motor boat. Maria Island is celebrated as the scene of a former convict settlement, and afterwards of various industrial experiments of the "wild-cat" type, in which much capital appears to have been sunk. The limestone rocks, of Permo-Carboniferous age, are crowded with fossils, which may be collected in unlimited quantity both in the "Fossil Cliff" on the shore and in an extensive quarry excavated to supply the now defunct cement works. Perhaps the most conspicuous of the fossils in the cliff is the large bivalve Eurydesma, but numerous others occur in profusion. A dredging trip in the neighbourhood of the island, in about 20 to 25 fathoms of water, yielded an enormous profusion of sponges in great variety, including some very remarkable and novel Calcarea. On the island itself numerous land planarians were collected, and the botanists were de- lighted to find the curious Tmesipteris growing upon tree-ferns.

The party left Maria Island early on Sunday, September 13, and after crossing to Spring Bay visited the kitchen middens at Little Swan Port. These were found to consist almost entirely of immense quantities of oyster-shells, forming a deposit several teet in thickness, and extending over a good many acres. The curiously rough chipped " flints," so characteristic of the Tasmanian aborigines, were found here in abundance. After lunch at Spring Bay the party motored back to Hobart through very beautiful scenery. This concluded the main part of the programme, but the zoological visitors remained by special invitation to take part in a collecting expedition to the Great Lake. Before leaving Hobart on this trip Prof. Dendy gave an address to the Royal Society of Tasmania on progressive evolution, and Dr. W. M. Tattersall delivered a public lecture on the depths of the sea. A visit was also paid to Mrs. Roberts in $\mathrm{H}$-bart, whose collection of living Tasmanian and other animals excited much interest, two "native devils" (Sarcophilus) with young ones being particularly admired.

The party for the Great Lake started from Hobart on the morning of September 16 in three motor cars, and reached their destination the same evening. It had been hoped that they would be able to obtain a good deal of marsupial and monotreme material for the committee appointed by the council of the British Association for that purpose, but these hopes were only very scantily fulfilled. No monotremes were seen, though tracks and burrows of Ornithorhynchus were found on the shore of the lake, and only a very few wallabies and rat kangaroos were obtained to represent the marsupials. The invertebrate fauna of the neighbourhood, however, yielded a large number of extremely interesting specimens. The shrimp-like Paranaspides was obtained in quantities by dredging in the lake, and under the stones along the shore were found Phreatoicus, numerous freshwater planarians (one of remarkably large size), etc.

The forest around the lake has unfortunately been ravaged by fire, but laborious turning over of the fallen timber yielded many most interesting cryptozoic animals, including the land nemertine (Geonemertes australiensis), which was fairly common, a number of species of land planarians, and several specimens of the rare Tasmanian Peripatus (Ooperipatus insignis). The visitors returned to Hobart on September 22, and some of them left Launceston for Melbourne by the s.s. Rotomahana on the following day.

In every respect the Tasmanian visit must be regarded as a very great success. The thanks of the visiting members are due to all who contributed so generously to this result, and especially to his Excellency the Governor of Tasmania (Sir W. EllisonMacartney) and Lady Ellison-Macartney, to the Premier and other members of the Government, to local scientific men, such as Mr. R. M. Johnston, Mr. Rodway and Mr. May, and, above all, to Prof. $T$. Thomson Flynn, the able and energetic organiser of the visit.

A. D

\section{AUSTRALIA AND THE BRITISH ASSOCIATION. ${ }^{1}$}

$\mathrm{T} T$ is just one hundred and forty-four years since the first scientific expedition from Great Britain to Australia visited Moreton Bay. The expedition consisted of his Majesty's barque Endeavour, a vessel which had been built for the coal trade and was chosen because she was an excellent seaI Concluding discourse delivered before the, British Association at Brisbane on August 3 I by Sir Edward Schäfer, F.R.S.

NO. 2353, VOL. 94] 